\title{
ANALISIS SEMIOTIKA DALAM IKLAN SHOPEE 12.12 BIRTHDAY SALE EDISI BLACKPINK
}

\author{
Adinda Rita Dara ${ }^{1}$, Muchlis ${ }^{2}$ \\ ${ }^{1,2}$ Universits Islam Negeri Sunan Ampel Surabaya \\ 1iindaabeadles@gmail.com, ${ }^{2}$ muchlis@gmail.com
}

\begin{tabular}{l}
\hline Article Info \\
\hline Article history: \\
Received 9 Agustus 2019 \\
Accepted 10 September 2019 \\
Published 5 Oktober 2019 \\
\hline
\end{tabular}

Keyword:

Makna, Citra Perempuan, Iklan Shopee, Edisi

Blackpink

\begin{abstract}
Meaning is a thought or reference that cannot be determined absolutely but is always in the relationship between symbol and reference. Meanwhile, image is a description of reality or perception that does not have to match what is described and must be different in every opinion. The focus of this research is how the meaning of the image of women is displayed in Shopee advertisements. This study uses Charles Sander Pierce's semiotic analysis technique with a critical approach. This technique is a way of looking at social reality that can occur in real life and can find out how to interpret women as objects in Shopee advertisements. From the results of this study, the researchers found that the image of women is described as attracting public interest to buy or use a product or service.
\end{abstract}

Makna merupakan pikiran atau referensi yang tidak dapat ditentukan secara mutlak melainkan selalu dalam relasi antara lambang dan acuan. Sedangkan citra merupakan gambaran tentang realitas atau persepsi yang tidak harus sesuai dengan apa yang tergambarkan dan pasti berbeda dalam setiap pendapat. Fokus penelitian ini adalah bagaimana makna citra perempuan ditampilkan dalam iklan Shopee. Penelitian ini menggunakan teknik analisis semiotika Charles Sander Pierce dengan pendekatan kritis. Teknik ini menjadi salah satu cara pandang terhadap realitas sosial yang dapat terjadi di dalam kehidupan nyata serta dapat mengetahui cara memaknai perempuan sebagai objek dalam iklan Shopee. Dari hasil penelitian ini peneliti menemukan, bahwa citra perempuan digambarkan sebagai penarik minat khalayak untuk membeli atau menggunakan suatu produk atau jasa tersebut.

\section{Editorial Office:}

Program Studi Ilmu Komunikasi, Fakultas Dakwah dan Komunikasi, UIN Sunan Ampel Surabaya. Jl. Ahmad Yani 117 Surabaya, Jawa Timur, Indonesia.

Email: jurnalilkom@uinsby.ac.id 


\section{Pendahuluan}

Pada saat ini, televisi termasuk salah satu media massa yang berpengaruh, sehingga masyarakat mengetahui dan memahami secara baik tentang segala informasi yang tersajikan. Masyarakat yang awalnya tidak mengetahui beberapa informasi, pada akhirnya mengetahui dan sadar tentang hal-hal yang terjadi di sekitarnya. Karena hal itu juga, televisi menjadikan masyarakat berperilaku konsumtif dan haus terhadap informasi. Tidak heran jika televisi mempunyai peran penting dalam perubahan yang signifikan di dalam masyarakat. ${ }^{1}$

Televisi dinilai efektif dalam menarik simpati masyarakat dengan menggabungkan audio dan visual yang yang tidak dimiliki oleh radio dan surat kabar. Dengan terciptanya ketertarikan tersebut, dapat dengan mudah membuat masyarakat menjadi lebih dekat dengan program yang telah disajikan. Saat menonton televisi, kita pasti akan melihat berbagai tayangan iklan baik iklan masyarakat maupun iklan komersil.

Dunia pertelevisian yang telah mengambil alih segala macam bentuk media informasi lainnya menjadi salah satu media yang berpengaruh dan menjadi penting serta menguntungkan bagi para produsen produk dan jasa dalam menginformasikan produk dan jasa mereka. Televisi telah menyiapkan banyak program untuk dinikmati oleh masyarakat seperti iklan. Tidak dapat dipungkiri, hal ini membuat televisi menjadi tempat yang

1 Marcel Danesi, Pengantar Memahami Semiotika Media (Yogyakarta: Jalasutra, 2010), 166. dituju oleh produsen untuk menginformasikan produk dan jasa mereka.

Periklanan dapat digunakan untuk menginformasikan suatu produk dan jasa dari para produsen yang dinilai sangat efektif bagi meningkatkan daya tarik masyarakat terhadap iklan yang ditayangkan. Dalam dunia periklanan, iklan dapat ditayangkan dengan menggabungkan audio dan visual yang dapat menarik masyarakat untuk melihatnya.

Iklan berperan sebagai sarana penyajian informasi nonpersonal dengan segala bentuk pesan yang diinginkan oleh produsen serta ditujukan kepada konsumen. Secara sederhana, iklan merupakan salah satu cara berkomunikasi yang efektif untuk digunakan dalam menyampaikan informasi. Hal tersebut dapat digunakan untuk membujuk masyarakat supaya menggunakan produk dan jasa yang telah dipromosikan. Semakin menarik iklan dibuat, maka kemungkinan minat masyarakat juga semakin besar. ${ }^{2}$ Oleh sebab itu, para produsen berlombalomba dalam membuat iklan dengan sekreatif dan semenarik mungkin hingga masyarakat akan mudah untuk selalu mengingatnya.

Secara perlahan-lahan, iklan telah mempengaruhi pandangan setiap masyarakat sehingga memberikan dampak berupa perubahan nilai sosial serta budaya yang cukup signifikan tetapi tidak dirasakan oleh masing-masing individu. Pada dasarnya setiap individu memiliki need,

\footnotetext{
${ }^{2}$ Marcel Danesi, Pengantar Memahami Semiotika Media, Jalasutra, Yogyakarta, 2010, h. 222
} 
wan, dan buy yang sama. Hal tersebut dapat membuat peiklanan semakin ramai digunakan sebagai senjata yang ampuh bagi setiap agensi yang akan mengiklankan produk atau jasa tersebut guna menciptakan pengaruh yang besar untuk masyarakat penikmat iklan. ${ }^{3}$

Dalam perkembangan iklan-iklan saat ini, lebih banyak menampilkan perempuan dan merepresentasikan dari kulktur iklan daripada kualitas produk yang diiklankan. Perubahan nilai budaya di Indonesia membuat produsen lebih mudah untuk menarik minat masyarakat, salah satunya yaitu menawarkan suatu produk dengan ikon yang menggambarkan perempuan. Perempuan dianggap sebagai penambah nilai jual bagi suatu produk yang sedang ditayangkan. Seperti contoh dalam iklan Shopee yang menggunakan Blackpink sebagai model dalam iklan tersebut. Menariknya, semakin banyak pengguna aplikasi Shopee berkat penayangan iklan promosi Shopee 12.12 Birthday Sale ini. Tercatat sekitar 74 juta unduhan di Indonesia hingga saat ini dan memperkuat posisi Shopee sebagai aplikasi belanja online nomor satu di Google Play dan App Store. $^{4}$

Atas dasar narasi di atas, peneliti ingin mengetahui bagaimana makna citra perempuan dalam iklan Shopee tersebut. Peneliti memilih iklan Shopee edisi Blackpink, dengan teknik analisis Semiotika Charles Sander Pierce.

\footnotetext{
${ }^{3}$ Oji Kurniadi, "Perempuan dalam Tayangan Iklan Televisi," Jurnal Komunikasi 1, no. 1 (2007), 103.

${ }^{4}$ Indotelko, "Pertumbuhan Pengguna Shopee Capai 150\%," accessed July 23, 2019.
}

Sedangkan tujuan penelitian ini adalah menjelaskan makna citra perempuan dalam iklan Shopee 12.12 birthday sale edisi Blackpink.

\section{Kajian Pustaka}

Istilah gender diperkenalkan oleh para ilmuwan sosial untuk menjelaskan perbedaan perempuan dan laki-laki yang bersifat bawaan sebagai ciptaan Tuhan dan yang bersifat bentukan budaya yang dipelajari dan disosialisasikan sejak kecil. ${ }^{5}$ Perbedaan peran gender ini sangat membantu setiap individu untuk memikirkan kembali tentang pembagian peran yang kerap kali disalahartikan dan dianggap telah melekat pada perempuan dan laki-laki untuk membangun gambaran relasi gender yang dinamis dan tepat dengan kenyataan yang ada dalam masyarakat.

Secara umum adanya gender telah melahirkan peran, tanggung jawab, fungsi dan bahkan ruang tempat dimana manusia beraktivitas. Hal tersebut terbentuk dari hasil konstruksi sosial budaya yang tertanam lewat proses sosialisasi dari satu generasi ke generasi berikutnya. Dengan demikian gender dapat diartikan sebagai hasil kesepakatan antar manusia yang tidak bersifat kodrati.

Teori gender ini tidak hanya melihat dari satu sisi, melainkan dari sisi laki-laki maupun perempuan. Hal tersebut terjadi karena terjadinya perbedaan peran antara

https://www.indotelko.com/read/1543462517/pert umbuhan-pengguna-shopee.

${ }^{5}$ Puspitasari, Herien. "Konsep, Teori, dan Analisis Gender.” Accessed July 23, 2019.

http://ikk.fema.ipb.ac.id/v2/images/karyailmiah/ge nder.pdf. 
laki-laki dan perempuan dimana keduanya memiliki ruang yang dapat digunakan untuk beraktivitas. Dalam hal ini dapat sangat membantu baik laki-laki maupun perempuan agar tidak terbatasi dan di salah artikan dengan budaya masyarakat yang telah melekat di kehidupan sehari-hari. Teori gender ini dapat membangun gambaran relasi yang dinamis dalam kehidupan sosial di masyarakat.

Hubungan laki-laki dan perempuan bukan dilandasi konflik dikotomis, bukan pula struktural fungsional, tetapi lebih dilandasi kebutuhan kebersamaan guna membangun kemitraan yang harmonis, karena setiap pihak memiliki kelebihan sekaligus kelemahan yang perlu diisi dan dilengkapi pihak lain guna menjalin kerjasama yang baik dan setara antara lakilaki dan perempuan.

Kebudayaan yang dimotori oleh budaya patriarki menafsirkan perbedaan biologis ini menjadi indikator kepantasan dalam perilaku yang akhirnya berujung pembatasan hak, akses, partisipasi, kontrol dan menikmati manfaat dari sumber daya dan informasi. Akhirnya tuntutan peran, tugas, kedudukan dan kewajiban yang pantas dilakukan oleh laki-laki atau perempuan dan yang tidak pantas dilakukan oleh laki-laki atau perempuan sangat bervariasi dari masyarakat satu ke masyarakat lainnya. Ada sebagian masyarakat yang sangat kaku membatasi peran yang pantas dilakukan baik oleh lakilaki maupun perempuan, seperti misalnya melihat laki-laki yang memasak di dapur. Namun ada juga sebagian masyarakat yang fleksibel dalam memperbolehkan laki-laki dan perempuan melakukan aktivitas sehari-hari, seperti perempuan naik ke atap atau memanjat pohon.

Perbedaan konsep gender secara sosial telah melahirkan perbedaan peran perempuan dan laki-laki dalam masyarakat. Secara umum adanya gender telah melahirkan perbedaan peran, tanggung jawab, fungsi dan bahkan ruang tempat dimana manusia beraktifitas. Sedemikian rupanya perbedaan gender melekat pada cara pandang masyarakat, membuat masyarakat sering lupa seakanakan hal itu merupakan sesuatu yang permanen dan abadi sebagaimana ciri-ciri biologis yang dimiliki oleh laki-laki dan perempuan.

Anggapan bahwa sikap perempuan feminim dan laki-laki maskulin bukanlah sesuatu yang mutlak, semutlak pemikiran manusia atau jenis kelamin dilihat dari sisi biologis. Oleh sebab itu, untuk memahami konsep gender harus dilakukan pembedaan antara gender dengan sex. Dimana gender merupakan perbedaan antara laki-laki dan perempuan yang dibentuk, dibuat dan dikontruksi oleh masyarakat dan dapat berubah sesuai dengan perkembangan zaman.

\section{Makna}

Makna (pikiran atau referensi) adalah hubungan antara lambang (simbol) dan acuan atau referen. Hubungan antara lambang dan acuan bersifat tidak langsung, sedangkan hubungan antara lambang dengan referensi dan referensi dengan acuan bersifat langsung. Batasan makna ini sama dengan istilah pikiran, referensi yaitu hubungan antara lambang dengan acuan atau referen atau konsep. Singkatnya, 
makna adalah hubungan antara kata (laksem) dengan konsep (referens), serta benda atau hal yang dirujuk (referen) ${ }^{6}$

Makna tidak terletak pada kata-kata melainkan pada manusia itu sendiri. Penggunakan kata-kata untuk mendekati makna yang ingin dikomunikasikan tidak selalu berhasil dengan sempurna. Demikian pula, makna yang didapat komunikan dari pesan yang tersampaikan akan menghasilkan perbedaan makna yang diinginkan. $^{7}$

Makna merupakan arti atau maksud yang tersimpul dari suatu kata, kemudian menghasilkan hubungan yang saling bertautan antara makna dan bendanya. Secara sederhana, makna dapat berbeda bagi setiap manusia yang mendengarkan. Jika suatu kata tidak bisa dihubungkan dengan bendanya, peristiwa atau keadaan tertentu maka tidak dapat menghasilkan makna dari kata tersebut.

Makna kata bersifat sangat subjektif. Dalam kehidupan sehari-hari, pasti setiap manusia memiliki sudut pandang berbeda yang dapat menyebabkan pergeseran makna sebuah kata dalam satuan kalimat. Dengan istilah lain, setiap kata terkadang memiliki makna yang luas. Komunikasi berlangsung apabila ada kesepakatan dari semua pihak yang terlibat. Bahasa dan makna akan membuat sebuah kerjasama antara komunikator dengan komunikan agar dapat menafsirkan pesan yang disampaikan. ${ }^{8}$

${ }^{6}$ Witono Warsidi, "Penggunaan Idiom pada Novel Ranah 3 Warna Karya A. Fuadi dan Implikasinya pada Pembelajaran Bahasa Indonesia di SMA," Skripsi (Lampung: Fakultas Hukum Universitas Lampung, 2014), accessed June 10, 2019,

http://digilib.unila.ac.id/1469/8/BAB\%20II.pdf,

\section{Citra Perempuan dalam Iklan}

Perempuan memiliki daya tarik tersendiri melalui penampilan fisiknya yang dapat membuat fotografer, kameramen, pengiklan, pemasar, dan sebagainya menjadikannya sasaran terfavorit dibandingkan dengan laki-laki. Tidak saja postur tubuh yang dapat mendatangkan daya tarik, bahkan dari ujung rambut hingga ujung kaki. Daya Tarik ini membuat tidak hanya lawan jenis, tetapi juga sesama jenis yang mengakui perempuan dapat menarik perhatian yang lebih.

Citra merupakan gambaran tentang realitas dimana realitas tidak harus sesuai dengan apa yang tergambarkan. Citra menurut seluruh manusia merupakan persepsi yang pastinya berbeda setiap pendapat. Beberapa gambaran subjektif tersebut seringkali cukup akurat, gamblang dan sangat detail, sehingga dapat sangat membantu menyesuaikan diri dengan realitas kongkrit pengalaman berbeda dari setiap manusia.

Citra erat kaitannya dengan media. Peran media dalam kehidupan sosial sudah tidak diragukan lagi. Walau kerap dipandang berbeda, tidak ada yang menyangkal bahwa perannya sangat signifikan di dalam masyarakat modern. Citra dianggap memiliki kemampuan khusus untuk mempengaruhi persepsi yang berbeda dari setiap masyarakat yang

${ }^{7}$ Alex Sobur, Analisis Teks Media (Bandung: PT. Remaja Rosdakarya, 2015), 20.

${ }^{8}$ Asnah Lulu, "Pengertian Makna Kata dan Jenis-jenisnya," Academia.edu, https://www.academia.edu/22410115/Pengertian_ Makna_Kata_dan_Jenis. 
melihat produk atau jasa yang ditawarkan, ditambah dengan penggunaan model iklan perempuan yang mendominasi pasar iklan.

Citra perempuan dapat dilihat melalui peran perempuan dalam kehidupan seharihari, serta tokoh yang terlibat dalam kehidupan disekitarnya. Perempuan dalam media massa, khususnya dalam media iklan, sering dikatakan sebagai perempuannya kaum lelaki. Hal ini dikarenakan di dalam realitas sosial perempuan selalu diibaratkan sosok yang lemah-lembut dan perayu. Tidak dapat dipungkiri, bahwa pencitraan perempuan di dalam media iklan digambarkan sebagai pelengkap laki-laki. Keindahan perempuan serta kekaguman lelaki terhadap kecantikan rupawan seorang wanita merupakan satu kesatuan yang utuh, dimana dengan menampilkan kecantikan perempuan yang tidak ada habisnya menjadi salah satu alat pancing bagi para pekerja seni dan juga tambang uang kaum kapital.

Ketika perempuan menjadi simbol dalam seni-seni komersil, maka kekaguman terhadap perempuan berubah menjadi diskriminatif dan tendensius, bahkan menjadi simbol-simbol dari kekuasaan kaum lelaki. ${ }^{9}$ Keindahan perempuan menempatkannya dalam keadaan stereotype yang membawanya kedalam sifat-sifat tersebut. Kenyataannya, perempuan selalu dituntut untuk tampil cantik dan seksi serta berperan sebagai sosok yang cerdas dan dapat melakukan segala hal yang biasanya dilakukan oleh

\footnotetext{
${ }^{9}$ Burhan Bungin, Pornomedia Konsturksi Sosial Teknologi Telematika \& Perayaan Seks di Media Massa, Kencana, (Jakarta, 2003), 130.
}

laki-laki. Stereotip ini yang menjadi ide dan citra sekaligus sumber eksploitasi perempuan di berbagai media massa khususnya iklan.

\section{Iklan Shopee Edisi Blackpink}

Iklan adalah suatu bentuk komunikasi massa mengenai suatu produk atau ide yang dibayar oleh satu sponsor tertentu. Iklan merupakan salah satu bentuk promosi yang paling banyak digunakan oleh perusahaan tertentu, karena hal ini memungkinkan untuk dijangkau masyarakat luas. ${ }^{10}$ Oleh karena itu, kemampuan iklan melalui media massa dalam menarik minat dan perhatian konsumen dapat meningkatkan nilai jual bagi suatu perusahaan.

Tujuan dasar iklan adalah pemberian informasi tentang suatu produk layanan dengan cara dan strategi persuasif. Agar berita atau pesan dapat dipahami, diterima, dan disimpan-diingat, serta adanya tindakan tertentu (membeli) yang ditingkatkan dengan cara menarik perhatian konsumen serta menimbulkan asosiasi yang dapat menggugah selera, agar tindakan sesuai dengan keinginan komunikator.

Dalam dunia periklanan pesan yang disampaikan sangat mempengaruhi nilai jual suatu produk atau jasa yang sedang diiklankan tersebut. Pemasangan iklan harus memperhitungkan apa yang harus disampaikan agar mendapat tanggapan sesuai dengan yang diinginkan. Untuk menampilkan kekuatan iklan tidak hanya

\footnotetext{
${ }^{10}$ Morissan, Periklanan Komunikasi Pemasaran Terpadu (Jakarta: Pranadamedia Group, 2010), 18.
} 
menyampaikan pesan secara verbal, tetapi juga pesan yang nonverbal agar mendukung kekuatan daya tarik dari iklan tersebut.

Iklan tersebut merupakan salah satu bentuk dari e-commers bisnis yang sering digeluti oleh masyarakat modern khususnya di Indonesia yang bertujuan untuk mendapatkan keuntungan serta meningkatkan produksi penjualan, dan juga untuk mendorong masyarakat untuk memiliki, mempromosikan, serta menjual kembali produk tertentu kepada para pelanggan lainnya.

Dengan demikian, iklan merupakan salah satu bentuk penunjang nilai jual suatu produk di kalangan masyarakat. Iklan Shopee menawarkan produk dengan sistem yang semakin mempermudah dalam hal berbelanja online, hal tersebut membuat semakin banyak masyarakat yang percaya sehingga tidak ragu untuk menggunakan aplikasi tersebut. Dalam hal ini, Shopee menggunakan model Blackpink sebagai nilai jual terhadap iklan tersebut. Tidak hanya itu, bahkan Shopee membuat acara dalam rangka ulang tahun Shopee dan tidak lupa mengundang Blackpink secara khusus untuk menarik minat masyarakat.

\section{Semiotika Model Charles Sander Pierce}

Semiotik merupakan suatu model dari ilmu pengetahuan sosial yang mempelajari tentang hubungan dengan unit dasar yang disebut dengan tanda. Dengan demikian, hakikat keberadaan suatu tanda dapat dipelajari dalam semiotik ini. Semiotika

${ }^{11}$ Sobur, Analisis Teks Media, 95.

12 Rendra Widyatama, Bias Gender dalam Iklan Televisi (Jakarta: Media Presindo. 2006), 21. dalam segi etimologis yang berasal dari bahasa Yunani yaitu semeion berarti "tanda". Tanda itu sendiri merupakan dasar dari konvensi sosial yang terbangun sebelumnya, dapat dianggap mewakili sesuatu yang lain. Semiotika dalam segi terminologis merupakan ilmu yang mempelajari berbagai macam objek, peristiwa, serta seluruh kebudayaan sebagai tanda. ${ }^{11}$

Tanda ada dimana-mana, "kata" adalah tanda, demikian pula gerak isyarat, lampu lalu lintas, bendera, bangunan, pakaian, iklan televisi, dan semua hasil kebudayaan manusia dapat menjadi tanda. Pierce bahkan menegaskan bahwa manusia hanya dapat berpikir dengan sarana tanda. Tanpa tanda, manusia tidak dapat berkomunikasi. ${ }^{12}$ Semiotika adalah ilmu yang mempelajari tentang tanda. Tandatanda (signs) adalah dasar dari seluruh komunikasi. ${ }^{13}$

Semiotika atau semiologi, pada dasarnya hendak mempelajari bagaimana kemanusiaan memaknai hal-hal. Dalam hal ini, komunikasi tidak dapat dicampurkan dengan memaknai suatu hal. Memaknai berarti objek-objek tidak hanya membawa informasi, melainkan hendak berkomunikasi tetapi juga mengkonstitusi sistem terstruktur dari tanda.

Menurut Peirce, prinsip mendasar sifat tanda adalah sifat representatif dan interpretatif. Representatif berarti tanda yang dapat mewakili sesuatu yang lain, sedangkan interpretatif merupakan konsep penggunaan tanda dari pemikiran ke orang lain berbeda-beda. ${ }^{14}$ Teori dari Peirce menjadi

13 Sobur, Semiotika Komunikasi (Bandung: PT. Remaja Rosdakarya, 2003), 15.

${ }^{14}$ Sobur, Analisis Teks Media, 97. 
grand theory dalam semiotika di mana gagasannya bersifat menyeluruh, deskripsi struktural dari semua sistem penandaan. Peirce ingin mengidentifikasi partikel dasar dari tanda dan menggabungkan kembali semua komponen dalam struktur tunggal.

Peirce memiliki ciri khusus dalam memaknai suatu hal yaitu dengan menggunakan teori segitiga makna (triangle meaning) yang di dalamnya terdapat tiga elemen utama, yakni representamen atau bisa disebut sebagai tanda, interpretan, dan objek. ${ }^{15}$ Sebuah tanda yang dapat mewakili sesuatu yang lain. Sesuatu yang lain dinamakan sebagai interpretan. Interpretan adalah konsep penggunaan tanda dari pemikiran ke orang lain berbeda-beda. Sedangkan acuan tanda disebut objek. Objek adalah sesuatu yang datang dari tanda. Apabila ketiga elemen makna itu berinteraksi dalam benak seseorang, maka muncullah makna tentang sesuatu yang diwakili oleh tanda tersebut.

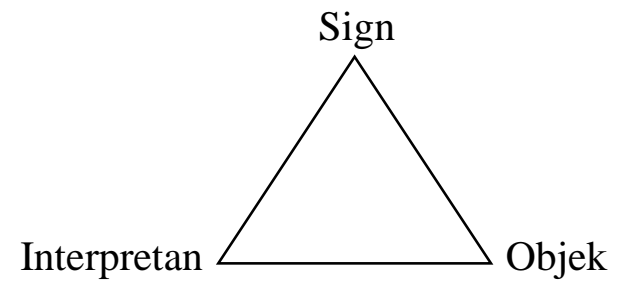

Gambar 1. Triangle Meaning

\section{Metode Penelitian}

Dalam hal ini peneliti menggunakan penelitian kualitatif tekstual. Peneliti ingin mengetahui bagaimana cara memaknai perempuan sebagai objek yang terdapat dalam iklan Shopee serta memahami sebuah fenomena dengan melakukan

15 Kris Budiman, Semiotika Visual: Konsep, Isu, dan Problem Ikonisitas (Yogyakarta: Jalasutra, 2011), 17. pengamatan, mencatat, dan menjabarkan hasil penelitian sesuai dengan pandangan dan gambaran yang sesuai dengan kenyataan. Dalam penelitian ini penulis menggunakan teknik analisis Semiotika C.S. Pierce. Peneliti mengambil contoh dalam media iklan Shopee di televisi khususnya di Indonesia yang mencakup bentuk tanda, objek dan interpretan. 
Hasil Penelitian dan Pembahasan

\section{Deskripsi Data Visual}

\section{Tabel 1. Deskripsi Data Visual}

Iklan Shopee berhasil membujuk khalayak untuk menggunakan aplikasi tersebut guna mencari atau bahkan membeli barang-barang yang berhubungan dengan

\begin{tabular}{|c|c|c|c|}
\hline & & & \\
\hline $\begin{array}{c}\text { Scene } 2 \\
\text { Detik ke-3 }\end{array}$ & & $\begin{array}{l}\text { Extreme Long Shot. } \\
\text { Member Blackpink yang sedang } \\
\text { menari di ruangan diiringi dengan lagu } \\
\text { milik Blackpink dengan background } \\
\text { gambar logo Shopee }\end{array}$ & $\begin{array}{l}\text { Lagu Blackpink } \\
\text { - Ddu Ddu Ddu }\end{array}$ \\
\hline $\begin{array}{c}\text { Scene } 6 \\
\text { Detik ke-9 }\end{array}$ & & $\begin{array}{l}\text { Medium Long Shot. } \\
\text { Salah satu member Blackpink yaitu } \\
\text { Lisa menggunakan baju hitam berdiri } \\
\text { disamping mobil dengan background } \\
\text { putih dan logo Shopee }\end{array}$ & $\begin{array}{l}\text { Lagu Blackpink } \\
\text { - Ddu Ddu Ddu }\end{array}$ \\
\hline $\begin{array}{c}\text { Scene } 12 \\
\text { Detik ke-17 }\end{array}$ & Gambar 1.12 & $\begin{array}{l}\text { Extreme Long Shot dengan teknik eye } \\
\text { level angel. Semua member Blackpink } \\
\text { menari bersama di dalam ruangan } \\
\text { dengan background logo Shopee yang } \\
\text { didominasi oleh warna oranye. }\end{array}$ & $\begin{array}{l}\text { Lagu Blackpink } \\
\text { - Ddu Ddu Ddu }\end{array}$ \\
\hline $\begin{array}{c}\text { Scene } 17 \\
\text { Detik ke-26 }\end{array}$ & 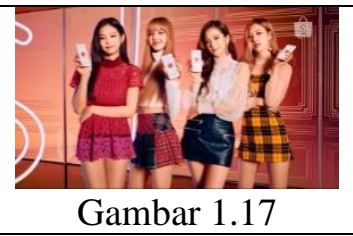 & $\begin{array}{l}\text { Medium Long Shot. } \\
\text { Semua member Blackpink masing- } \\
\text { masing memegang ponsel yang } \\
\text { menunjukkan gambar logo Shopee }\end{array}$ & $\begin{array}{l}\text { Lagu Blackpink } \\
\text { - Ddu Ddu Ddu }\end{array}$ \\
\hline
\end{tabular}

\section{Perempuan Digambarkan sebagai Penarik Khalayak}

Dalam hal menarik minat khalayak adalah untuk membeli produk atau jasa tersebut. Dalam segi estetika, penggunaan perempuan sebagai model dalam iklan sangatlah berpengaruh terhadap iklan tersebut. Pasalnya, tidak hanya kaum lakilaki yang menyukainya tapi tidak menutup kemungkinan para wanita juga menyukai iklan tersebut. Faktor kecantikan perempuan yang memang sebagai idaman perempuan ditambah dengan penggunaan Blackpink sebagai model iklan ini, membuat perempuan ingin menjadi cantik seperti Blackpink. Lalu kemudian membeli apa yang sedang diiklankan oleh Blackpink, atau menggunakan barang yang digunakan Blackpink.
Blackpink seperti album atau goodies yang sedang digunakan Blackpink. Lebih dalam lagi, Shopee juga menyediakan skin care yang digunakan oleh orang-orang Korea seperti Blackpink. Hal tersebut semakin menambah masyarakat di Indonesia khususnya kaum perempuan untuk membeli sesuatu yang berhubungan dengan Blackpink agar dapat mempercantik diri layaknya orang Korea.

Memang di dalam iklan tersebut Blackpink menggunakan pakaian sedikit terbuka dan hal tersebut sangat berbeda dengan keseharian masyarakat Indonesia. Akan tetapi, dalam iklan tersebut tidak hanya menjualkan bagaimana Blackpink berpakaian. Dalam hal ini Blackpink juga mempromosikan beberapa aksesoris yang digunakan dalam iklan tersebut. Dewasa 
ini cukup banyak masyarakat yang tertarik dengan produk-produk skin care import dari Korea. Tidak hanya kaum perempuan, tetapi laki-laki juga ingin berpenampilan menarik layaknya orang Korea yang memiliki kulit sehat.

Dalam iklan ini, Blackpink juga digambarkan sebagai perempuan yang suka berbelanja atau disebut sebagai shopaholic. Dimana hal tersebut menggambarkan perempuan masa kini yang hobi berbelanja dan mudah tergiur akan diskon dan barang baru yang mereka lihat. Penggunaan Blackpink sebagai model dalam iklan ini juga untuk menarik minat masyarakat dalam hal berbelanja online di aplikasi Shopee ini dengan jaminan keamanan produk selama penjualan dan akan sampai di alamat yang dituju. Perempuan di Indonesia semakin menyukai belanja online tersebut karena aplikasi Shopee yang menjual berbagai macam kebutuhan seperti kosmetik ala Korea yang di cari-cari kaum perempuan. Hal tersebut membuat Shopee semakin dibanjiri pelanggan dan membuat produk atau jasanya tersebut semakin dikenal dan diingat oleh khalayak.

Dewasa ini, semakin banyak masyarakat yang menginginkan kecantikan seperti Blackpink. Hal tersebut membuat Shopee semakin gencar untuk mempromosikan produknya dengan menggunakan Blackpink tersebut yang membuat khalayak semakin tertarik dan ingin menggunakan aplikasi tersebut untuk transaksi belanja online. Iklan telah membentuk sebuah ideologi tentang makna di kalangan perempuan Indonesia. Iklan yang disampaikan oleh media massa sekarang ini dapat memberikan pengaruh yang sangat besar dalam mengkontruksi arti kecantikan dalam lingkungan sekitar.

Seperti contoh dalam analisis data yang menggunakan model C.S. Pierce, analisis ini berfokus pada makna citra perempuan yang tergambar dalam iklan Shopee edisi Blackpink.

Dalam iklan Shopee ini menampilkan bahwa untuk selalu tampil cantik dan mudah dalam menarik khalayak, perempuan menggunakan cara dalam hal mempertegas kewanitaannya yang telah tercipta secara biologis. Dengan menggunakan pakaian yang mini tetapi tetap dapat menarik perhatian masyarakat sehingga pengguna Shopee juga semakin banyak baik dikalangan remaja maupun dewasa.

\section{Analisis Scene 1, Detik ke-3}

Blackpink menggambarkan sebagai perempuan yang lebih menonjolkan sisi perempuannya. Hal ini dibuktikan oleh Blackpink dalam iklan Shopee ini, yang berarti bahwa perempuan dapat memperjuangkan hak-haknya atau keinginannya dalam pranata sosial yang ada di kehidupan sehari-hari.

Iklan Shopee edisi Blackpink ini membantu perempuan khususnya di Indonesia untuk dapat melakukan suatu hal yang sesuai dengan kemampuan dan keinginannya. Peran perempuan yang selama ini hanya berlaku pada pekerjaan rumah tangga, sekarang perempuan dapat menyetarakan kedudukan dengan laki-laki dalam hal pranata sosial agar tidak dipandang rendah oleh masyarakat sekitar. Perempuan juga dapat melakukan aktivitasnya seperti bernyanyi atau menjadi model 
layaknya Blackpink dalam iklan Shopee ini.

\section{Analisis Scene 3, Detik ke-9}

Perempuan bisa memiliki sikap girly dan anggun, serta menjelaskan bahwa perempuan juga bisa memiliki sikap yang berani dan tegas. Berani disini dalam arti yang berani menyampaikan pendapat secara tegas dan tidak selalu bergantung kepada laki-laki meskipun memang tidak dalam segala hal perempuan dapat berjalan sendiri tanpa bantuan laki-laki. Dengan pandangan mata yang tajam tetapi masih menampilkan kecantikan perermpuan, hal tersebut juga terjadi dalam kehidupan nyata. Dimana perempuan yang cantik, anggun, dan lembut juga memiliki pandangan mata yang tajam agar terlihat tegas dan tidak dianggap rendah oleh baik laki-laki maupun perempuan lainnya.

Rasa percaya diri dengan kemampuan yang dimilikinya dan berani mengungkapkan pendapatnya adalah poin penting dalam menunjukkan sisi lain dari perempuan agar tidak selalu di anggap rendah dibandingkan dengan laki-laki. Lisa menunjukkan bahwa perempuan berhak untuk menggapai keinginannya selain dalam urusan mengurus rumah tangga seperti yang ada dalam kehidupan nyata ini.

\section{Analisis Scene 6, Detik ke-17}

Pada gambar di atas menjelaskan bahwa kecantikan perempuan pada jaman sekarang memang diperlukan meskipun bukan sebagai kebutuhan utama. Karena jaman sekarang semua sudah semakin canggih dan modern, akhirnya perempuan di Indonesia juga berlomba-lomba untuk mempercantik diri agar lebih percaya diri dan dihargai. Pada jaman modern seperti sekarang ini, perempuan dapat dengan mudah untuk mempercantik diri dengan gaya yang sesuai dengan selera masingmasing. Ditambah dengan pemilihan style guna menunjang kecantikan dari diri perempuan tersebut.

\section{Analisis Scene 8 detik ke-26 gambar 1.17}

Kecantikan perempuan pada jaman sekarang memang diperlukan meskipun bukan sebagai kebutuhan utama. Karena jaman sekarang semua sudah semakin canggih dan modern, akhirnya perempuan di Indonesia juga berlomba-lomba untuk mempercantik diri agar lebih percaya diri dan dihargai. Pada jaman modern seperti sekarang ini, perempuan dapat dengan mudah untuk mempercantik diri dengan gaya yang sesuai dengan selera masingmasing. Ditambah dengan pemilihan style guna menunjang kecantikan dari diri perempuan tersebut. Saat ini para perempuan juga ingin menambah pertemanan yang sama-sama bisa merasakan sisi dari genderme tersebut. Seperti kesamaan bekerja di dunia modeling, dengan usaha dan ketekunan untuk merubah mindset masyarakat bahwa perempuan hanya dapat bekerja di rumah untuk keluarganya.

Hal tersebut dapat membuat mereka sama-sama merasa apa yang dirasakan oleh salah satu sama lain dan akan membuat pikiran mereka terbuka untuk mencari jalan keluar dari permasalahan tersebut. Sayangnya, tidak semua perempuan berpikiran terbuka untuk mengikuti perubahan jaman yang terjadi saat ini. Lingkungan yang kurang mendukung untuk melakukan sedikit perubahan bisa 
sangat mempengaruhi. Dari bukti yang di dapat di lapangan, alasan kenapa memang masih banyak perempuan di Indonesia yang masih berpikiran sempit adalah karena faktor keluarga, lingkungan dan pola pikir yang tidak mendukung adanya perubahan tersebut. Sehingga membuat masih banyak perempuan yang tetap mempertahankan masa lalunya dan lebih memilih mengabdi kepada keluarga tercinta.

\section{Analisis Semiotika dalam iklan Shopee 12.12 Birthday Sale edisi Blackpink}

Teori gender merupakan perspektif atau teori yang mengeksploitasi makna konsep perbedaan peran, tanggung jawab, fungsi dan bahkan ruang tempat dimana manusia beraktifitas. Sedemikian rupanya perbedaan gender melekat pada cara pandang masyarakat, membuat masyarakat sering lupa seakan-akan hal itu merupakan sesuatu yang permanen dan abadi sebagaimana ciri-ciri biologis yang dimiliki oleh laki-laki dan perempuan.

Dalam hal ini, telah diamati bahwa teori gender tidak hanya melihat dari satu sisi, melainkan dari sisi laki-laki maupun perempuan. Hal tersebut terjadi karena terjadinya perbedaan peran antara laki-laki dan perempuan dimana keduanya memiliki ruang yang dapat digunakan untuk beraktivitas. Teori gender ini dapat membangun gambaran relasi yang dinamis dalam kehidupan sosial di masyarakat.

Dalam iklan Shopee ini, citra perempuan digambarkan sebagai penarik minat masyarakat terhadap aktivitas berbelanja online. Jika dikaitkan dengan teori gender, dalam iklan ini perempuan juga dapat dikaitkan dengan perannya untuk menarik peminat khalayak terhadap iklan yang sedang ditayangkan tersebut. Perempuan memang diciptakan memiliki kelebihan yang kaum laki-laki tidak miliki. Dilihat dari segi estetika kaum perempuan khususnya di Indonesia memiliki kecantikan yang natural. Sehingga membuat kaum laki-laki tertarik akan hal tersebut. Akan tetapi dalam iklan ini menggunakan Blackpink sebagai model dan membuatnya semakin banyak yang tertarik dan menyukai iklan tersebu jika dilihat dari sisi gender perempuan.

Konsep gender dalam iklan ini adalah seperti contoh dalam scene yang menampilkan member Blackpink. Dalam hal ini, Blackpink digambarkan sebagai perempuan yang memiliki daya tarik agar dapat merubah pandangan masyarakat terhadap perempuan yang selalu dipandang rendah. Karena pada dasarnya konsep gender adalah menyamaratakan peran dan tugas yang dijalani baik laki-laki maupun perempuan sehingga keduanya tidak terbatasi oleh budaya masyarakat yang selama ini melekat. Sehingga masyarakat dapat menyadari bahwa perempuan juga dapat melakukan kegiatan yang laki-laki kerjakan seperti bekerja dan bersosialisasi dengan lingkungan baru, serta laki-laki yang juga dapat melakukan pekerjaan rumah seperti memasak. Meskipun hal tersebut terjadi, tetapi perempuan tidak melupakan kodratnya untuk melakukan pekerjaan rumah dan menjaga keluarganya.

Untuk menjadi perempuan yang berpikiran terbuka harus dapat berpikiran 
seimbang antara keinginan dan kewajiban yang harus dilakukannya. Perempuan dapat bekerja atau melakukan aktivitas yang diinginkan, tetapi tidak melupakan kegiatan dirumah seperti menjaga anak dan keluarga serta merawat rumah tangga sehingga menjadi keluarga yang harmonis dan utuh.

\section{Kesimpulan}

Dari penelitian yang penulis lakukan terhadap iklan Shopee untuk melihat makna citra perempuan yang ingin disampaikan oleh agensi pembuat iklan dengan pendekatan analisis semiotika Charles Sander Peirce dan menggunakan teori gender. Penulis telah menghasilkan suatu kesimpulan yang merupakana hasil penafsiran sendiri. Oleh karena itu, kesimpulan yang penulis tarik dari peneliti ini, mungkin saja terdapat beberapa perbedaan cara pandang dan interpretasi dari orang lain saat melihat tayangan iklan Shopee ini.

Dalam iklan Shopee ini menggambarkan perempuan yang ingin selalu tampil cantik dan menarik, aktif, mandiri, dan percaya diri. Dalam hal ini, aktif adalah perempuan yang dapat menyanyi dan menari dalam satu waktu. Sedangkan mandiri adalah perempuan yang dapat melakukan segala hal sendiri, seperti berbelanja kebutuhan, bekerja, serta melakukan kegiatan yang diinginkan.

\section{Daftar Pustaka}

Budiman, Kris. Semiotika Visual: Konsep, Isu, dan Problem Ikonisitas. Yogyakarta: Jalasutra, 2011.
Bungin, Burhan. Pornomedia Konsturksi Sosial Teknologi Telematika \& Perayaan Seks di Media Massa. Jakarta: Kencana, 2003.

Danesi, Marcel. Pengantar Memahami Semiotika Media. Yogyakarta: Jalasutra, 2010.

Indotelko. "Pertumbuhan Pengguna Shopee Capai 150\%." Accessed July 23 , 2019. https://www.indotelko.com/read/1543 462517/pertumbuhan-penggunashopee

Kurniadi, Oji. "Perempuan dalam Tayangan Iklan Televisi," Jurnal Komunikasi 1, no. 1 (2007).

Lulu, Asnah. "Pengertian Makna Kata dan Jenis-jenisnya." Academia.edu, https://www.academia.edu/22410115/ Pengertian_Makna_Kata_dan_Jenis.

Marhaeni, Dian. "Representasi Anak-Anak Dalam Tayangan Iklan Komersial di Media," Jurnal Komunikasi 1, no. 1 (2010).

Morissan. Periklanan Komunikasi Pemasaran Terpadu. Jakarta: Pranadamedia Group, 2010.

Puspitasari, Herien. "Konsep, Teori, dan Analisis Gender." Accessed July 23, 2019.

http://ikk.fema.ipb.ac.id/v2/images/ka ryailmiah/gender.pdf.

Sahetapy, Wilma Laura dan Luhukay, Marsefio Sevyone. "Perempuan dan Citranya (Analisis Semiotik Pemaknaan Citra Perempuan dalam Iklan Garnier, Vaseline, Rexona dan 
Giv),“ Laporan Penelitian. Surabaya:

LPPM Universitas Kristen Petra,

2012. Accessed July 23, 2019.

http://repository.petra.ac.id/16744/1/L

aporan_Akhir_Penelitian_wilma.pdf.

Sobur, Alex. Analisis Teks Media.

Bandung: PT. Remaja Rosdakarya, 2015.

Sobur, Alex. Semiotika Komunikasi.

Bandung: PT. Remaja Rosdakarya, 2003.

Warsidi, Witono. "Penggunaan Idiom pada Novel Ranah 3 Warna Karya A. Fuadi dan Implikasinya pada Pembelajaran Bahasa Indonesia di SMA," Skripsi. Lampung: Fakultas Hukum Universitas Lampung, 2014. Accessed June $\quad 2019$. http://digilib.unila.ac.id/1469/8/BAB \%20II.pdf,

Widyatama, Rendra. Bias Gender dalam Iklan Televisi. Jakarta: Media Presindo. 2006.

Windasari, Miranti. "Persepsi Pegawai Bank Perempuan Terhadap Promosi Jabatan Berkriteria Penampilan Modis (Studi Deskriptif terhadap Pegawai Bank Perempuan di BNI Cabang Medan)," Skripsi. Medan: Universitas Sumatera Utara, 2010. Accessed July 23 , 2019. http://repository.usu.ac.id/bitstream/h andle/123456789/18102/Chapter\%20I I.pdf 